\title{
Roman Catholicism versus Pentecostalism: The nexus of fundamentalism and religious freedom in Africa
}

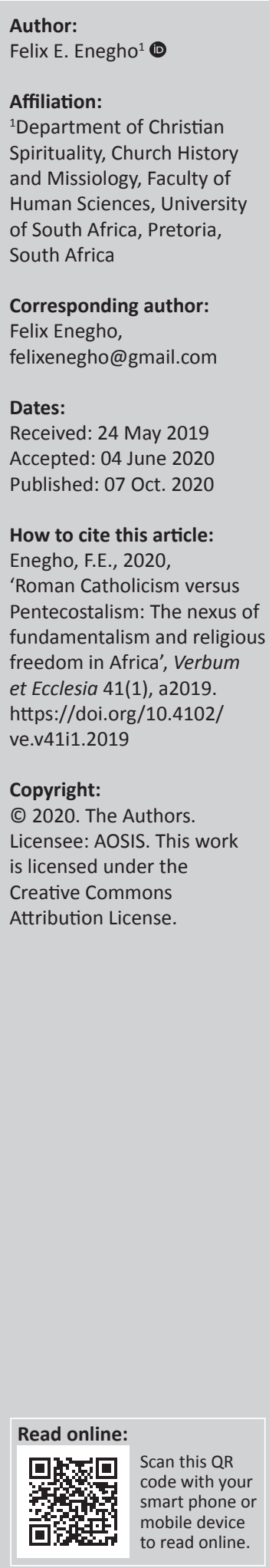

Today's Christians in the age of secularism and other kinds of ideologies struggle to make their impacts felt as they assiduously labour to plant the gospel in the hearts and minds of many. Amid their struggles and worries, they are often confronted with other challenges both from within and outside. The aim of this research was to assess the Roman Catholic Church and her struggle in the midst of other Churches often tagged 'Pentecostals' in the areas of fundamentalism and religious freedom in Africa and most especially in Nigeria. Pentecostal theology was aligned with Evangelism in their emphasis on the reliability of the Bible and the great need for the spiritual transformation of the individual's life with faith in Jesus Christ. They emphasise personal experience and work of the Holy Spirit and therefore see themselves as a selected few, who are holy, spiritual and better than others. Some of them even claim to have the monopoly of the Holy Spirit. This researcher was one scholar who holds the view that there was no church more Pentecostal than the Catholic Church which has survived for more than 2000 years under the influence and direction of the Holy Spirit. But for the sake of this research, there was the categorisation of the Church into Catholicism and Pentecostalism. Here, the researcher focused on the challenges to faith witness and evangelisation posed by the rise of Pentecostalism in Africa and particularly in Nigeria. This research adopts a combination of socio-historical and narrative approaches. The data gathering technique was the main source made up of books, unpublished materials, journal articles and Internet materials.

Intradisciplinary and/or interdisciplinary implications: The research has relevance to Church History, Dogmatic Theology and Practical Theology. While from the interdisciplinary perspective, the work has relevance in Psychology and other fields in the Social Sciences. The research does not call for a change in traditional discourse, but rather to build on the existing status quo.

Keywords: fundamentalism; religious; freedom; Pentecostalism; Roman; Catholic; Charismatic renewal; evangelisation.

\section{Introduction}

The Catholic Church in Africa and in our world has continued to fight in all spheres of life to make the Gospel of Christ entrenched in the lives of many. Africa at the moment is part of the stronghold of the Catholic Church in our world today as there are many in both the clergy and the lay faithful who daily carry out the tasks of preaching the Goodnews to all creatures. It is imperative to admit here that when issues of evangelisation are mentioned within Catholicism, it is not so easy to forget the role played by the foreign missionaries who left their comfort zones in Europe, North America and other parts of the world in order to plant the good news for the enlightenment of Africans about Christ and by doing so fulfilling the Great Commission of Jesus that those who believe in Him must go into all the world to preach His message to every human being on this earth.

In Nigeria, the Catholic Church has been deeply planted and watered. The Church has grown in leaps and bounds and over the years has become a missionary church sending workers into those countries that once evangelised Nigeria and other parts in Africa. This work focuses on the challenges to faith witness and evangelisation posed by the rise of Pentecostalism in Africa and particularly in Nigeria. There is also the assessment of religious fundamentalism and religious freedom in Africa. However, the scope of this article would be within the confines of Nigeria and some parts of Africa where applicable. 


\section{Pentecostalism, fundamentalism and their impacts on African Catholicism with focus on Nigeria}

Pentecostalism is a longstanding phenomenon, but it has assumed particular relevance only in modern times. Many beautiful concepts are most times corrupted with the passage of time by the absorption of aberrations and sentiments that are difficult to be traced to the original concepts. What began as Pentecost gradually grew into Pentecostal and invariably ended up as Pentecostalism. This is the same way too in which Fundament metamorphosed into fundamental and Fundamentalism. ${ }^{1}$

The pure matter in respect of Pentecost is the sending of the Holy Spirit upon the apostles so that they would become witnesses to the Lord Jesus throughout the world (Ac 1:8). Although we do not, as yet, know the details of what happened on that Pentecost morning, we are sure of the accompaniments, the results or what followed. The apostles had locked themselves up in the room, not because movements were restricted as for the period of the Census, but because they were afraid of the Jewish authorities who had just killed their Master. But when the power came through the outpouring of the Holy Spirit, the change in them was spectacular. ${ }^{2}$

The precious Baptism turned the internal weakness of the Church into power by striking from its founders that inward evil principle of hindrance and unfettering them in freedom never before experienced. His coming turned pale profession into a lively activity, timidity into holy boldness, cowardice into fearlessness, stinginess into liberality, leanness of soul into the buoyancy of spirit and fragility of trust unto undaunted faith and heroic action. This accounts for why the greatest need of the Church today is the Holy Spirit. In the absence of the Holy Spirit there can be no real progressive soul-winning programme. Ecclesiastical organisation, social fellowship and humanitarian work all in the name of Jesus Christ would not add up to much and would indeed be dead if they are devoid of the Holy Spirit. The change from being without to being with the Holy Spirit is like that from the light of the Moon to the light of the Sun. This experience is called in modern parlance and terminology, being 'born again'. ${ }^{3}$

When Pentecostals see Catholics, they ask, 'Have you been born again?' Sometimes, professional Catholic theologians take the Pentecostals through rigmarole of sophisticated theological jargons that confuse rather than convince. What this succeeds in achieving is often to convince the young, simple-minded inquirer that we are not yet real Christians in the true sense. How would they not ask many Catholics if they are born again when they cannot see any vibrancy, any

1.Michael Elue (2007:71)

2.Michael Elue (2007:71-72)

3.Elue (2007:72). conviction, any candour, any joy in our proclamation of the Gospel of Christ? How would they not think otherwise when all they can see is perhaps the effects of the original push of grace? When we look pale, with no smile when we are celebrating a dull and boring liturgy, how could we convince anybody that we ever received that powerful agent of transformation and yet remain as insipid and lukewarm as we appear? It is mainly this weakness on our part that the Pentecostals are exploiting to their great advantage. ${ }^{4}$

There is another use of the word to describe those Christians in the mainline Churches who have been influenced by the Pentecostal emphasis on experience and spiritual gifts but remain in their traditional churches, like the Lutheran Charismatic or the Catholic Charismatic Renewal. In other words, the Charismatic movement or the Catholic Charismatic Renewal is the name usually given to Pentecostals as it has taken shape in the mainline Protestant Churches and in the Orthodox and Roman Catholic Churches. In Africa today, the words Fundamentalism, Pentecostalism and Charismatic can often mean the same thing. They are often used interchangeably of the same group of Christians. Most Fundamentalists on the African continent seem to be Pentecostal or Charismatic as well. It is this Pentecostal kind of Fundamentalism that is on the increase in a large scale. This is the Christianity that is spreading through Revivals, Adoration Ministry and workshops that have become the features of many African cities, including Nigeria. This is the Christianity spread through the radio and television programmes, popular literature, new ministries and bible colleges and more recently through the Internet. ${ }^{5}$

The impact of Pentecostalism on African and also Nigerian Catholicism cannot be overemphasised. The Catholic Charismatic Renewal has been a subject of great controversy in Nigeria and elsewhere around the world for quite some time now. The reason could largely be because of some activities of the group perceived by most people within Catholicism as anti-Catholic. Since the advent of the group into the Catholic Church in 1967 and its emergence into the Catholic Church in Nigeria in the 1970s, many Roman Catholics have persistently asked for its careful study. The Catholic Charismatic Renewal as a Lay Apostolate group in the Church has continued to emphasise the working of the Holy Spirit in the lives of individual members and on the entire Church. ${ }^{6}$

In his work, The Household of God, Leslie Newbigin ${ }^{7}$ casts Pentecostalism in terms of a 'third force' in Christianity, following the Protestant emphasis on the Word, and the Roman Catholic emphasis on the Sacraments. In Africa, the precursors of Pentecostalism were indigenous prophet

4.Michael Elue (2007:72).

5.Michael Elue (2007:73).

6.Felix Enegho (2010:50)

7.Kalu Ogbu (2007:340). 
figures, many of whom were persecuted out of historic mission denominations for pursuing spiritualities sometimes scandalously perceived by church authority as belonging to the 'occult'. Prophets William Wade Harris of the Gold Coast (now modern Ghana), Garrick Sokari Briade of the Niger Delta, Simon Kimbangu of the Congo and others challenged Africans to throw away their traditional resources of supernatural succour and turn towards the living God of the Bible.

Charismatic renewal movements in Africa born entirely out of lay initiatives with support from a few clergy, simply to integrate renewal phenomena within existing mainline denominations in order to renew them from within. The formation of these movements constitutes one way in which to understand how African Christians actually set to work in practical ways the Christian message as understood in their vernacular Scriptures in which God was encountered as Holy Spirit. An international example worthy of mention is the Catholic Charismatic Renewal Movement which having started in Duquesne in the United States of America in 1967, now operates within Roman Catholic denominations worldwide with the African versions being among some of the most dynamic. ${ }^{8}$

Rudolf Otto ${ }^{9}$ laments the inability of 'orthodox Christianity' to recognise the value of the non-rational aspect of religion, thus giving the 'idea of the holy' what he expresses as 'a one-sidedly intellectualistic approach'. Pentecostalism is a response to such cerebral Christianity, and wherever it has appeared, the movement has defined itself in terms of the recovery of the experiential aspects of the faith by demonstrating the power of the spirit to infuse life and the ability of the living presence of Jesus Christ to save from sin and evil. This is even more so in Africa where religion is a survival strategy, and where spirit possession with its emphasis on direct divine communication, intervention in crises and religious mediation are central to religious experiences. The ministries of healing and deliverance have thus become some of the most significant expressions of Christianity in African Pentecostalism. Charismatic movements practise 'healing and deliverance' widely within their mission churches largely because it is in high demand. For example, prior to his being called to Rome in 1982, 'healing and deliverance' was the specialty of Zambian Catholic exorcist, Archbishop Emmanuel Milingo. In most parts of the African continent, Charismatic renewal movements, where they have been tolerated along with such ministries to the possessed and oppressed, have helped historic mission denominations to recover from the haemorrhage they used to suffer by the drift of their members into Pentecostal churches. Pentecostalism has, through its various streams, become such a forceful movement in Africa to the extent where churches refusing to integrate its spirituality in one form or another know they face atrophy.

8.Kalu Ogbu (2007:346)

9.Kalu Ogbu (2007:346).
One other form of fundamentalism is the acceptance and application of Scriptural text at the face value, so that anything outside this is not acceptable no matter its authenticity. This leads to the danger of neglecting the Sacred Traditional as a true source of Revelation besides the Scripture. The presence, measure and the operation of modern Pentecostal movements are indeed real challenges to the mainline Churches, especially the Catholic Church in Africa, particularly in Nigeria. Catholics have been challenged to re-examine their faith and the expressions of their faith, their pastoral structures and methodologies, and the training of their ministers and other pastoral agents. They have also been challenged to embark on serious catechetical formation of her members both the young and old..$^{10}$

\section{Is there religious freedom in African Christianity?}

When we analyse Christianity in Africa, we always tend to blame other religions for the woes suffered by Christians and Christianity in the past. But oftentimes, we fail to realise that Christianity also encroached into the freedom of other forms of religion in time past and even in our contemporary time, not just in the Western world, but on the African continent as well. The first theoretical element that by definition forms the basis for the absence of dialogue in mission is exclusivism; the idea or, indeed, the conviction that one's own religion is the true religion. Within Christianity, this is symbolically represented by the famous saying of Fulgentius Ruspe: extra ecclesiam nulla salus. Even if this saying is framed in a Christian context, it has a universal meaning. The potential sins of the Christian mission resulting from exclusivism are by no means exclusive. Exclusivism is a mindset, a way of interpreting the world, which is characteristic of humanity's infancy. One would assert that while all cultures - and religions are part of them - have gone through this phase of development, some of them have not yet completed it. Just as all children are born self-centred and subconsciously enjoy being the focus of their family, so religions are egocentric when they emerge. They believe they offer the only means to salvation and have an innate superiority complex. It was time, history, experience and the advancement of human knowledge that enabled Christianity to overcome its egocentricity. Christianity came to realise that it is not the centre of the world, that there are other equally valid reference points and that relations with them should be driven not by domination and antipathy but by dialogue. ${ }^{11}$

\section{Fundamentalism and intolerances as basis for Chaotic Christianity}

Edward O. Connor highlighted what could be regarded as the inherent dangers in Pentecostalism. But coming from persons who are not Pentecostals, one may be tempted to perceive the entire analysis as defensive mechanism by people who tend to spoil the works of others. But it is most 10.Jake Otonko (2005:102)

11.Jose Maria Vigil (2012:18-19). 
likely that even when the Holy Spirit is the root power that has spurred up a movement, not everything in it can be attributed to Him. The gifts conferred by the Holy Spirit may be exploited for the wrong motives or mistaken ways and the genuine imitated by the counterfeits. The Pentecostal movement even when it seems to be the work of the Holy Spirit in its roots and principal impulse is also a complex mixture of human energies that, in part, correspond to the Spirit's plan, but, in part, deviates from it, conflict with the counterfeits. The following brings about chaotic Christianity. ${ }^{12}$

New evangelism from the perspective of the Catholic church in its broad sense means evangelising the world as it is today, which is in the process of complete transformation, a world increasingly being unified by science, technology, a globalising economy and means of communication; a world which is confronted with new problems and challenges, for example, religious indifferentism and absolute relativism; consumerism along with practical atheism; excessive accumulation of wealth on the one hand and poverty, illiteracy, ill-health and every form of exploitation on the other hand and rise of ethnic confrontations; weakening of religious faith in some regions of the world (including the African continent), in contrast to deepening of religious fundamentalism and emergence of aggressive sects in others, growing secularisation of society as against manifestations of devious forms of spirituality. ${ }^{13}$

\section{Evaluating evangelisation in Pentecostalism and Catholicism in Nigeria}

The act of converting people to Christianity is the work of God, while evangelism is the task of men and women. It is a mistake to think that it is the function of evangelism to produce converts. Only God can save a person and bring that person to himself. Apostle Paul makes it very clear when he said (1 Cor 3):

I planted the seed, Apollos watered it, but God made it grow. So, neither he who plants nor he who waters is anything, but only God who make things grow. (v. 6,7)

Evangelism is definitely very significant. 'How can they believe... without someone preaching to them?' (Rm 10:14). The task of evangelism is an instructional process, which focuses primarily on the intellect rather than on the emotions. Evangelism should be seen not as mere sob stories, scarce tactics, manipulation of people or any other form of psychological pressure. Evangelism is purely the explanation of the gospel message. ${ }^{14}$

Pentecostalism and its growth in Africa today may not be strategically demonstrated in an accurate fashion. But it is highly visible and has reshaped the religious landscape.

12.Michael Elue (2007:77).

13.Felix Enegho (2014:212).

14.Felix Enegho (2014:210).
All Christian forms are growing in Africa, but Pentecostalism enjoys the fastest growth rate. Two surveys conducted in Ghana in the 1980s and 1990s confirm a general trend. It is prominently at the cutting edge of Christian development at the end of millennium. Scholars have made observation that its liturgy and temper catalysed the charismatisation of the mainline churches. The main features of the movement include an intensive evangelistic fervour and passion for mission. ${ }^{15}$

Many parts of the African continent witnessed the sudden surge of young puritan preachers in the 1970s. They signified a new dimension in revivalism in the post-independence era. Another cycle of revival swept through the continent bringing with it a religious tradition whose face has changed drastically in every decade and whose full import is still in the making. That spiritual revival that swept through Nigeria in the 1970s created a phenomenon that is now regarded as 'born again' movement. From the Nigerian perspective, this terminology covers both Pentecostal and charismatic movements. It has acquired various hues and become complex but its origin was a wave of charismatic movements among the youth of various denominations which occurred in different parts of the country and eddied into churches, challenging the parent groups who allegedly suffered from 'power failure'. The charismatic goals were both to re-evangelise the mainline churches, as well as to win new souls for the kingdom. Evangelism and passion for the kingdom remained central to whatever followed. ${ }^{16}$

It needs to be put in perspective to indicate the lines of continuity with older flares of revivals. Nigeria witnessed several charismatic stirrings from 1914 to 1975: firstly, was the prophetic movement at the turn of the 20th century; secondly, revivals among some missionary churches such as the Qua Iboe Mission from Wales and the Apostolic churches including the Babalola revival within the Christ Apostolic; and thirdly, was a variety of the Aladura (African Instituted Church). The argument is that the charismatic movement from the 1970s was unique. It is possible to weave connections between the three and to show the differences. This phenomenon did not benefit from the proverbial 'resources of externality'. Although it became significant after political independence and during the long process of decolonising African churches, yet it had little to do with the nationalist ideology that suffused the politics of independence. The youth derailed the path of decolonisation of the churches by reshaping the religious landscape along charismatic lines and away from the indigenisation strategies of the mission churches. ${ }^{17}$

It is significant to mention certain details because there were six components to this phenomenon: the Hour of Deliverance ministry which operated in Lagos before the Nigerian Civil War broke out; the Benson Idahosa ministry which was just 15.Kalu Ogbu (2007:9-10).

16.Ogbu (2007:11).

17.Kalu Ogbu (2007:11-12). 
gathering momentum in Benin City when the NigerianBiafran Civil War commenced; the radicalisation of the Scripture Union in Eastern Nigeria that occurred in the years 1967-1975; the Hour of Our Freedom ministry which started in the midst of the civil war in 1969 and blossomed in the eastern Nigeria in the immediate aftermath; as well as the growth of the Christian Union in Nigerian universities. In 1971, several of the university graduates from the southern regions of Nigeria served in northern Muslim regions under the compulsory National Youth Service Corps programme. They established the 'Corpers as Preachers' programme. Meanwhile, some Roman Catholic Students joined the charismatic fellowships. These trends catalysed the movement before divisions emerged when some of the young men founded independent charismatic churches. Perhaps we can use the Scripture Union as the mascot or signifier to reconstruct the spiritual temper of the times to demonstrate how the various groups co-operated under the fire of the Holy Spirit. ${ }^{18}$

The religious landscape during the Nigerian-Biafran Civil War situation is equally a significant backdrop. It took many forms: there was a cultural renaissance because scarcity of money and social suffering enlarged the space for native doctors, the ancient cultures of communities and especially social control models. Occult groups flourished because dire times needed quick solutions. The Aladura, who had not been very successful in certain parts of the country because of the strength of mission churches, now proliferated as the prayer houses were established in the hinterland at the heels of fleeing refugees. The mission churches had much competition because their organised structures could not be maintained. Roman Catholic priests and nuns ran for safety after losing their congregations in the urban areas. British support for the Nigerian government disillusioned and angered many who thought that 'Christian' England would easily recognise that eastern Nigerians constituted the bulwark of Christianity in the Nigerian nation. Patriotic propaganda harped on this perfidy, leaving the insinuation that western-type Christianity was not a reliable part. Many turned to the syncretistic prayer houses to deal with the inner and physical needs of the war condition. So, ironically, the middle ground of Christianity gave way as the culture shifted to either the prayer houses or to the young radicalised Scripture Union (SU) boys and girls. ${ }^{19}$

In similar ways of oral transmission and more, the Catholic Charismatic Renewal has truly affected the life of the church in the area of evangelism. Within the Catholic Church, the Charismatic Renewal members just like most members of other pious societies in the church such as the Legion of Mary, the Blue Army are seriously involved in helping to evangelise so as to bring lost souls to Christ. They also help retain members within the church who would have left for other denominations of Christianity. Through evangelism, the Catholic Charismatic Renewal in Nigeria has helped to start new outstations and parishes. Somehow, because of 18.Kalu Ogbu (2007:12).

19.Kalu Ogbu (2007:13). their dynamism and moral uprightness, some members of the Catholic Charismatic Renewal easily stand out even in the crowd. Such members do not only evangelise with their words, but also with their actions. ${ }^{20}$

However, witness of life alone is not enough; there is also the need for verbal preaching. This is because 'faith is heard and what is heard comes by the preaching of Christ' (Rm 10:17). For Pope Paul VI, 'the spoken word has always its excellence and efficacy and this is especially true when it proclaims the power of God'. This necessitates orthodoxy, for the church's proclamation has essential content that cannot be modified without serious dilution of its nature. There are some Roman Catholics who are of the view that individual or group preaching by the Catholic Charismatic Renewal members should not be at variance with that of the Roman Catholic Church. We recall that when Christ sent out the apostles, he asked them to teach all he had commanded, nothing more or else (Mt 28:19). What Christ commanded is handed down to us from the apostles through their writings as contained in the Bible and word of mouth (Tradition cf. 2 Th 2:15). There are many who believe that some members of the Catholic Charismatic Renewal discard the church's tradition; forgetting that the same bible commands the Christians to believe the church's traditions (2 Th 2:15). ${ }^{21}$

This researcher opines that while it may be true that some members of the Renewal may be fanatical in their total disregard of the traditions of the Catholic Church, it should also be noted that if in the cause of evangelism some members of the Catholic Charismatic Renewal step on the 'toes' of some members of the hierarchy of the church, that should be expected. In evangelism, there are certainly 'no sacred cows'. If there are some traditions of the Roman Catholic Church that needs to be addressed by the evangelists in the Renewal, it should be expected. It is quite unfortunate that some members of the hierarchy of the Roman Catholic Church are possibly more concerned with the image of the church than with the person of Christ. There is absolutely nothing wrong with change. But unfortunately, the Roman Catholic Church is most likely slow to change in many areas. For this reason, the hierarchy of the church most times cry 'wolf' when some members of the Catholic Charismatic Renewal try to initiate change in some areas for the good of the church. Jesus Christ and his disciples faced opposition from the Jewish religious authorities on a constant basis. To bring about positive change was the reason for the apostolate of the ministry of Jesus and his disciples, and they never bothered about who gets offended. If they were docile, Jesus would not have been crucified and his disciples after him would not have been persecuted and consequently martyred. ${ }^{22}$

The authorities of the Roman Catholic Church and the entire institution - the church certainly need to be respected by the 20.Felix Enegho (2007:179).

21.Felix Enegho (2007:179-180).

22.Felix Enegho (2007:180). 
faithful including the members of the Catholic Charismatic Renewal. But if evangelism is to be proactive in the Roman Catholic Church, there is the need to be purified with the Holy Spirit. This involves correction of any person or traditions within the church that need to be corrected. The Charismatic Renewal members in the Catholic Church should be like some prophets of old who were ready to speak to any person(s) or traditions no matter the repercussion, as long as it is for the good of the church. Authentic evangelism by the Catholic Charismatic Renewal members just like other members of the church should be to proclaim the good news of Christ even at the risk of one's life. Even Apostle Paul had challenged Apostle Peter who at the time was the leader of the early church. Paul said (Gl 2):

Now when Peter had come to Antioch, I withstood him to his face because he was to be blamed; for before certain men came from James, he would eat with the Gentiles; but when they came, he withdrew and separated himself, fearing those who were of the circumcision... (vv. 11-14)

One wonders how many within the hierarchy of the Roman Catholic Church would today want to be told that they are wrong when it is crystal clear that there is certainly something not right in their actions or in some traditions within the church. $^{23}$

\section{Research findings}

Based on the literature utilised in this work, this author arrived at the following as research findings:

- That the curtailment of the religious freedom of individuals and communities is not only a painful experience but is above all an attack on human's very dignity, independently of the religion professed or of the concept of the world which these individuals and communities have; and the curtailment and violation of religious freedom are in contrast with the dignity of the human person in Africa and our global community

- That the Pentecostal movement even when it seems to be the work of the Holy Spirit in its roots and principal impulse is also a complex mixture of human energies that, in part, correspond to the Spirit's plan, but in part deviates from it, conflict with the counterfeits. The following brings about chaotic Christianity

- That the act of converting people to Christianity is the work of God, while evangelism is the task of men and women. It is a mistake to think that it is the function of evangelism to produce converts. Only God can save a person and bring that person to himself.

\section{Recommendations}

In this millennium as we constantly strive to propagate the gospel of Christ in a more technological and secularised world, there is the need for the hierarchy of the church in Africa whether Roman Catholic or non-Catholic churches to note the following recommendations:

23.Felix Enegho (2007:180-181).
- The church must be seen as being part of the world and therefore create models that would enhance the proper understanding of Christianity to both the Christians and non-Christians alike. Fundamentalism exists because many Christians including Roman Catholics have halfknowledge of the Christian faith and doctrine. The end result is aggression and hatred for those they consider enemies because of their non-realisation of the true meaning of Christianity.

- Roman Catholics must be made to realise that Pentecostalism is not an enemy to the gospel of Christ, but that the church in every sense of the world is Pentecostal in nature. Denominational rivalry must not be encouraged.

\section{Conclusion}

The Roman Catholic Church has continued to work for the expansion of God's kingdom here on earth through her many missionaries either in the clergy or/and the many dedicated laymen and women scattered all around the world. As the focus of this article is on Africa, there is the need to emphasise that the African church has been contributing to the development of global Christianity. This article focuses on the challenges to faith witness and evangelisation posed by the rise of Pentecostalism in Africa and particularly in Nigeria. While the efforts of the Pentecostals are deeply appreciated by many in Africa in the area of evangelism and mission in general, it is significant to reaffirm the challenge it has posed to the Roman Catholic Church. It has, to a large extent, challenged the Catholics in the area of evangelism. The implication is that the charismatics within the Catholic Church have continued to live out their lives in the mission of the church, thereby helping to reignite the fire of the Pentecost within Roman Catholicism.

However, where there exist people with different views and ideologies, there also exist some tendencies that may likely bring about crises of beliefs and convictions. The goal of the Roman Catholic Church is not to create a super church within Christianity, but to be co-workers with Christians of other denominations. The goal of Christianity is based on the vision for the messianic salvation which is proclaimed through the life, death and resurrection of Jesus Christ and which in Biblical terms is described as liberation, righteousness, justice and peace (Jorgensen 298). When we refer to Christian communities, fundamentalism and religious freedom, we envisage Christians irrespective of denominational affiliation as part of Christian communities in various parts of Africa just as elsewhere around the world. This calls for ecumenical spirit, whereby believers in Christ learn to live among one another and with people of other religions. Fundamentalism arises when Christians try to interpret God's words from their own denominational convictions and often times throughindividual understanding of the Scriptures. The quest to push one's views or opinions down the throats of others with regard to the hermeneutical interpretation or literary interpretation of the Bible and practices of one's denominations often times bring about fundamentalism and invariably religious extremism which if not properly handled, leads to religious crises. 
At this juncture, there is the need to point out the fact that there is no perfect point of view in our world or among any particular denomination in Christianity. The Catholic Church in her mission must learn to continuously cooperate with Christians of other denominations and with adherents of other religions. The road to religious freedom in Africa is a long one, but it is achievable with a careful understanding of the feelings and ideologies of the various Christian missions which call for tolerance. The Dignitatis humanae ${ }^{24}$ is the Second Vatican Council's stated intention 'to develop the doctrine of recent popes on the inviolable rights of the human person and the constitutional order of society' and it spells out the Church's support for the protection of religious liberty. It set the ground rules by which the church would relate to secular states... (Dignitatis humanae, Internet source).

Therefore, this article is not the final arbiter in the whole drama of proffering likely solutions to the challenges faced by the Roman Catholics in her relations with the Pentecostals; it is a call for continuous dialogue as we seek to understand one another as we journey in our Christian race. As Christians, we must continue to fight for the rights of the human person and invariable for the protection of religious freedom not only in Africa, but in our global community and the Catholic perspective of evangelisation should continue to be the watchword of all Catholics, while at the same time we must strive to collaborate with others including the Pentecostal Christians in making the Kingdom of God possible on the African continent and the global community.

\section{Acknowledgements Competing interests}

The author has declared that no competing interest exists.

24.Latin: (Of the Dignity of the Human Person) is the Second Vatican Council's Declaration on Religious Freedom.

\section{Author's contributions}

This work is the contribution of Felix Ehimare Enegho.

\section{Ethical consideration}

This article followed all ethical standards for a research without direct contact with human or animal subjects.

\section{Funding information}

This research received no specific grant from any funding agency in the public, commercial or not-for-profit sectors.

\section{Data availability statement}

Data sharing is not applicable to this article as no new data were created or analysed in this study.

\section{Disclaimer}

The views and opinions expressed in this article are those of the authors and do not necessarily reflect the official policy or position of any affiliated agency of the authors.

\section{References}

Elue, M., 2007, 'The challenge of Pentecostalism in the Nigerian Church', in N. Amuluche Greg (ed.), The new religious movements: Pentecostalism in perspective proceedings of the $21^{\text {st }}$ conference of the Catholic Theological Association of Nigeria, p. 71, Ava Publishers, Benin City.

Enegho, F., 2007, 'The Catholic Charismatic renewal of Nigeria, 1971 - 2000: A case study of three selected cities', A PhD dissertation Submitted to the Department of Christian Religious Studies, Lagos State University, Ojo - Lagos, p. 179.

Enegho, F., 2010, 'The Catholic Charismatic renewal in Nigeria', in O.E. Alana \& F.E. Enegho (eds.), Understanding Christian studies: Selected issues, vol. 1, p. 50, Nathadex Publishers, Ilorin.

Enegho, F., 2014, 'The destiny of the unevangelized in Christ: An assessment', Anyigba Journal of Arts and Humanities 13(3):209-217. https://doi.org/10.1177/ 1474022214539423

Otonko, J., 2005, Pentecostals and us: A dynamic reality, p. 102, Snaap Press Ltd., Enugu.

Ogbu, K., 2007, 'Pentecostalism and mission in Africa, $1970-2000$ ', Mission Studies, Journal of the International Association for Mission Studies 24(1):9-10, 340. https://doi.org/10.1163/157338307X191561

Vigil, J.M., 2012, 'Mission is dialogue and only dialogue', in K. Klaus \& V. Klaus (eds.), Mission and dialogue: Approaches to a communicative understanding of mission, pp. 18-19, Claretian Publications, Qyezon City. 